KULTURA

i

\title{
Z NADZIEJĄ PRZECIW BEZNADZIEI — RUCH PIQUETEROS JAKO PRZYKŁAD SAMOSTANOWIENIA ŚWIATA WYKLUCZONYCH
}

\begin{abstract}
„Będziemy wiedzieć, że zaczęła się nowa epoka nie wtedy, gdy nowe elity przejmą władzę lub gdy pojawi się nowa konstytucja, ale wtedy, kiedy zwykli ludzie zaczną walczyć o swoje interesy w nowy sposób".
\end{abstract}

Charles Tilly, The Contentious French

W ostatnim dziesięcioleciu XX wieku Ameryka Łacińska stała się, jak twierdził Ryszard Kapuściński (2001), prawdziwym laboratorium społecznym, kolebką innowacyjnych i nie spotykanych wcześniej ruchów społecznych protestujących przeciwko niesprawiedliwości i walczących o lepszy świat. Wiele krajów tego regionu jest dziś areną gwałtownych protestów grup, które - do tej pory marginalizowane i pozbawione podstawowych zasobów oraz dostępu do instytucji politycznych - postanowiły wyjść z ukrycia i walczyć z neoliberalną polityką oraz z jej skutkami. Walczyć o godność, wolność i sprawiedliwość. Wystarczy chociażby wspomnieć zapatystów w Meksyku, brazylijski ruch wydziedziczonych rolników bez ziemi - „Sem terra”, ruch ubogich Indian w Ekwadorze, Unię Bezrobotnych w Urugwaju, cocaleros w Boliwii, Narodową Federację Chłopów z Paragwaju, masowe ruchy bezrobotnych i biednych z Dominikany oraz mieszkańców slumsów Wenezueli czy wreszcie bezrobotnych w Argentynie (piqueteros).

Wielu badaczy z zainteresowaniem śledzi te ruchy społeczne, dostrzegając $\mathrm{w}$ nich ogromny potencjał oraz zapowiedź nowego okresu w dziejach - nie tylko tego regionu. Spośród innych aktorów politycznych wyróżnia je użycie niekonwencjonalnych (często niekonstytucyjnych) metod w celu zmiany sytuacji społecznej oraz zmuszania władz do spełnienia (przynajmniej części) ich postulatów. Rezygnacja z tradycyjnej polityki oraz podjęcie owych niekonwencjonalnych działań, obejmujących zarówno rozmaite taktyki konfrontacyjne

Adres do korespondencji: alina.stanaszek@wp.pl 
(strajki, demonstracje), jak i akty przemocy, wynika z tego, że uczestnicy ruchu $\mathrm{w}$ większości nie mają dostępu do polityki, brakuje im szeroko pojętych zasobów oraz mają poczucie, że inaczej ich głos nie będzie słyszalny (McAdam, Snow 1997, s. 326). Za sprawą specyficznych form ekspresji politycznej dążą do kształtowania opinii publicznej oraz wywierania nacisku na rządzących (Taylor, Van Dyke 2004).

Takie działania budzą niejednoznaczne reakcje. O ile takie masowe ruchy protestu jak Pomarańczowa Rewolucja na Ukrainie w 2004 r. spotkały się $z$ raczej szerokim poparciem i zostały uznane za znak przebudzenia społeczeństwa obywatelskiego oraz wołanie o demokrację, o tyle ruchy społeczne, z którymi mamy do czynienia w ostatnich latach w Ameryce Łacińskiej, nie są tak powszechnie aprobowane, gdyż de facto są wystąpieniami przeciwko demokratycznie wybranym rządom, a więc mogą być postrzegane jako atak na demokrację. W wielu krajach latynoskich masowe protesty spowodowały długotrwały paraliż, przyczyniając się do zmian w obrębie władz państwowych: dymisji rządów lub prezydentów (np. w Argentynie doszło do dymisji czterech prezydentów w ciągu trzech tygodni), a tym samym destabilizując sytuację w państwie.

$\mathrm{Na}$ pewno jednak ruchy te są fenomenem społecznym wartym głębszej analizy. Ich pojawienie się można traktować jako przejaw kryzysu legitymizacji współczesnego kapitalizmu, a także jako próbę poszukiwania alternatywnych form dla tradycyjnie pojmowanej demokracji reprezentatywnej, takich które na nowych prawach włączałyby również wyłączonych. Zjawisko to zostanie prześledzone na przykładzie argentyńskiego ruchu piqueteros ${ }^{1}$, który jest jednym $z$ najbardziej prężnych i skutecznych nowych ruchów antysystemowych ostatnich lat (Arrighi, Hopkins, Wallerstein 1989). Stanowi on przykład przezwyciężenia stereotypów mówiących o bierności biednych i wykluczonych. W powszechnej świadomości przyjęło się bowiem przekonanie, iż osoby żyjące w ubóstwie trudno zmobilizować do jakichkolwiek działań zbiorowych, gdyż atomizacja oraz podrzędne usytuowanie w strukturze społecznej sprawiają, że są oni raczej przeszkodą aniżeli inicjatorami zmian, czy to na poziomie indywidualnym, czy systemowym Odmawia się im potencjału sprawczego oraz podmiotowości uznając, iż nie są w stanie kontrolować własnego życia.

Masowa działalność bezrobotnych w Argentynie stanowi zaprzeczenie tego typu postaw, jest dowodem na to, że biedni mogą i, co więcej, potrafią się zorganizować. Ruch piqueteros, w moim przekonaniu, można potraktować jako przejaw woli samostanowienia wśród ludzi wykluczonych, którzy mimo faktycznego upośledzenia i zajmowania w społeczeństwie marginalnej pozycji pokazują swoim działaniem, iż są w stanie podjąć próbę zmiany własnej sytuacji

${ }^{1}$ Nazwa pochodzi od ich głównego narzędzia wyrazu, jakim są pikiety oraz blokady dróg. Te formy wyrazu sprzeciwu i niezadowolenia w ostatnich latach stały się popularną taktyką stosowaną przez grupy marginalizowane w Ekwadorze, Boliwii, Paragwaju, Brazylii oraz Kolumbii. 
oraz społecznego wizerunku. Jest to przypadek, który warto analizować ze względu na jego skalę i potencjał oraz wzorcotwórczą rolę pełnioną wobec innych krajów, nie tylko Ameryki Łacińskiej. Jednak aby zrozumieć jego specyfikę, należy przywołać kontekst, w jakim zaistniał, gdyż — jak twierdzi znawca problematyki ruchów społecznych, Alaine Touraine - „nie można analizować ruchu społecznego poza obrębem historyczności, w której powstaje [...]. Przedmiotem analizy socjologicznej nie może być nigdy sam ruch społeczny, musi to być pole działania społecznego, w którym ruch społeczny jest jednym z aktorów" (cyt. za: Sztompka 2005, s. 235).

\section{„KTO SIEJE NIESPRAWIEDLIWOŚĆ, ZBIERA PIQUETEROS”2}

Argentyński ruch piqueteros jako wyrazista platforma działania wyłonił się $\mathrm{w}$ połowie lat dziewięćdziesiątych, a jego uczestnicy protestowali przeciwko zamykaniu fabryk i zwalnianiu robotników. Protesty te pojawiły się w szczególnym momencie: gdy obowiązujący paradygmat społeczno-polityczno-gospodarczy — od lat znajdujący się w poważnym kryzysie — zaczął pękać, a coraz więcej aktorów życia społecznego zaczęło go kwestionować, walcząc o jego renegocjację lub nawet obalenie i skonstruowanie nowych zasad.

Zainicjowane wówczas przemiany wytworzyły „sprzyjający kontekst strukturalny", który — jak twierdzi Neil Smelser (1962) — jest jednym z kilku niezbędnych warunków powstania ruchu społecznego. Towarzyszyło temu swoiste „strukturalne napięcie”, a więc ewidentne sprzeczności interesów oraz narastające konflikty. Argentyna przechodziła wówczas okres głębokich przemian społecznych, politycznych i gospodarczych. Ubóstwo i bezrobocie przyjęło bezprecedensowe rozmiary, dramatycznie zaczął pogarszać się poziom życia ludności. Niekorzystna sytuacja częściowo była spadkiem po dyktaturze, rządzącej krajem w latach 1976-1983. To negatywne dziedzictwo pogłębiło się podczas prezydentury Ráula Alfonsina (1983-1989), a kulminacja nastąpiła za rządów prezydenta Carlosa Menema (1989-1999) oraz jego następcy Fernando de la Rua (1999-2001). Menem i jego minister finansów Dominigo Cavallo od początku lat dziewięćdziesiątych XX wieku realizowali liberalny program ekonomiczny, zapewniając społeczeństwo, iż w ten sposób Argentyna stanie się częścią „Pierwszego Świata”. Jednak obiecany cud gospodarczy nie nastąpił, a kraj znalazł się na skraju poważnego kryzysu społeczno-gospodarczego. Strukturalne dostosowywanie argentyńskiej gospodarki do zaleceń Międzynarodowego Funduszu Walutowego i Banku Światowego jeszcze bardziej pogłębiało niekorzystną sytuację kraju. Zlikwidowano wiele fabryk, pozbawiając pracy setki tysięcy osób. Najbardziej ucierpieli na tym biedni i niewykształceni, mający mniejsze możliwości ponownego odnalezienia się na rynku pracy. Jednocześnie za rządów Menema wprowadzono reformę prawa

\footnotetext{
2 Napis na murze w Buenos Aires.
} 
pracy, przez co zwiększyła się możliwość zatrudnienia, ale głównie na zasadzie elastycznych umów o pracę i kontraktów tymczasowych. Miało to na celu obniżenie kosztów pracy, lecz w istocie stworzyło możliwość łatwego zwalniania pracowników, pozbawiając ich jakichkolwiek zabezpieczeń i pewności zatrudnienia oraz doprowadzając do upowszechnienia się zjawiska, które Pierre Bourdieu (1999) określił jako wyzysk oparty na elastyczności (flexploitation).

Rząd, próbując spłacać długi, zdecydował się na radykalne cięcia budżetowe w sferze edukacji, opiece zdrowotnej, pomocy społecznej, zwiększył przy tym wydatki na policję i wojsko. Doszło też do prywatyzacji wielu sektorów gospodarki, co jeszcze bardziej pogłębiło kryzys finansów publicznych, powodując ogromną nieufność obywateli do władzy ${ }^{3}$. Co więcej, z roku na rok pogłębiała się pauperyzacja społeczeństwa oraz wzrastało bezrobocie ${ }^{4}$. Jednocześnie państwo nie troszczyło się o sytuację osób pozbawionych pracy, a z zasiłków (bardzo niewielkich) korzystało zaledwie 5\% z nich (95 tys. z 1 mln 700 tys. bezrobotnych w 1997 r.) (Auyero 2000).

Podobne zmiany zachodziły w wielu krajach Ameryki Łacińskiej, gdzie wdrażano liberalne reformy, ale - jak podkreślają znawcy problematyki tego regionu, James Petras i Henry Veltmeyer (2002), w żadnym kraju negatywne skutki reform (masowe bezrobocie ${ }^{5}$, drastyczne zmniejszenie się dochodów ludności ${ }^{6}$ ) nie były tak błyskawiczne i tak głębokie jak w Argentynie. Poza tym sytuacja „wyjściowa” była tu stosunkowo najbardziej korzystna, jeśli weźmiemy pod uwagę względnie obiektywne parametry: Argentyna miała najbardziej rozwiniętą gospodarkę, najwyższy poziom życia w regionie, najbardziej wykwalifikowaną siłę roboczą, znaczną klasę średnią, a jednocześnie najbardziej zdeterminowaną ekipę rządzącą, chcącą wypełniać zalecenia międzynarodowych instytucji finansowych.

${ }^{3} \mathrm{~W}$ ostatnim etapie rządów prezydenta de la Rua jego poparcie społeczne wynosiło zaledwie $4 \%$ (CS 2003, s. 113).

${ }^{4}$ Według danych Komisji ONZ ds. Ameryki Łacińskiej, liczba Argentyńczyków żyjących poniżej linii ubóstwa wzrastała w dramatycznym tempie: 1992 r. było to $15 \%$ społeczeństwa, w $2000 \mathrm{r}$. $30 \%$, a w czerwcu 2002 r. już ponad $51 \%$ obywateli (18,2 mln). Ubóstwo dotknęło także dzieci, a zlikwidowanie na żądanie Międzynarodowego Funduszu Walutowego szkolnych programów dożywiania sprawiło, że w niektórych regionach ok. $60 \%$ dzieci cierpiało z powodu niedożywienia, a zasłabnięcia z głodu były częstym zjawiskiem w wielu szkołach (Petras, Veltmeyer 2002).

${ }^{5}$ Restrukturyzacja gospodarki, masowe zwolnienia z prywatyzowanych przedsiębiorstw oraz uelastycznienie kodeksu pracy doprowadziły do masowego bezrobocia. Bezrobocie, które w $1974 \mathrm{r}$. wynosiło ok. 10\%, w 1995 r. wzrosło do 30\%, a w 2002 r. wynosiło blisko 40\% (na wsiach ok. 60\%) (INDEC 2002). Tylko w latach 1989-1999 w wyniku prywatyzacji pracę straciło ponad 150 tys. osób (Auyero 2000).

6 Poza grupą $10 \%$ najbogatszych obywateli dochód pracowników we wszystkich sektorach oraz emerytów zmniejszył się średnio o 67\%. Według danych Agendy ONZ ds. Rozwoju (UNDP) w 1997 r. dochód na głowę jednego Argentyńczyka wynosił 8950 dol., a w marcu 2002 r. 3197 dol. (Petras, Veltmeyer 2002). 


\section{POCZĄTKI WIELKIEJ REBELII}

Ruch dojrzewał powoli, zwłaszcza jeśli uwzględnimy dramatyczną sytuację w kraju. Początkowo, w drugiej połowie lat dziewięćdziesiątych, niewielkie grupy bezrobotnych, zwalnianych z prywatyzowanych przedsiębiorstw, w różnych regionach kraju protestowały przeciwko likwidowaniu miejsc pracy. Państwowe przedsiębiorstwa zostały sprzedane zagranicznym właścicielom, nastąpiło otwarcie gospodarki, co spowodowało gwałtowny napływ zagranicznych towarów, a w konsekwencji doprowadziło do ruiny małych lokalnych producentów, którzy nie byli w stanie sprostać konkurencji z zewnątrz. Sytuacja zaczęła się zaostrzać, kiedy w czerwcu 1996 r. w Cutral-Co, małym mieście w południowej Patagonii ${ }^{7}$, po prywatyzacji państwowej fabryki $z$ branży paliwowej (YPF) doszło do masowych zwolnień (z 4000 pracowników pracę zachowało 400 osób) (CS 2003, s. 116). W odpowiedzi na tę decyzję zdesperowani robotnicy przez sześć dni blokowali kluczową drogę krajową. Ich działania (okupacja fabryk i budynków rządowych, blokady dróg) rozszerzały się wraz z pogłębianiem się kryzysu ekonomicznego ${ }^{8}$.

Czara goryczy przelała się pod koniec 2001 r., gdy okazało się, że kolejne rządy nie spełniają obietnic przedwyborczych i mimo początkowego odcinania się od działań poprzedników kontynuują ich neoliberalną politykę, dramatycznie rośnie bezrobocie, a nierówności społeczne pogłębiają się coraz bardziej ${ }^{9}$. Aby móc spłacać długi, wprowadzono ustawę, która konfiskowała lub zamrażała prywatne oszczędności obywateli. Decyzja ta bezpośrednio przyczyniła się do wybuchu zamieszek w całym kraju. Stała się ona, używając kategorii Smelsera (1962), swoistym „zdarzeniem inicjującym”. Rozpoczęło się dwudniowe powstanie narodowe (19-20 grudnia). Wówczas to w istocie narodził się ruch piqueteros. Tłumy obywateli (dane o liczbach, w zależności od źródeł, mówią o 100 tys. lub nawet 200 tys. demonstrantów) wyległy na ulice, domagając się dymisji rządu. Demonstracje stały się swego rodzaju sojuszem ponad podziałami - braterstwem broni łączącym wszystkie „ofiary” polityki rządu. Wzięli w nich udział nie tylko bezrobotni, młodzież, emeryci, pracownicy obawiający się utraty pracy, działacze związkowi, organizacje walczące o prawa człowieka (Matki z Plaza de Mayo), ale także przedstawiciele klasy średniej, która również straciła swoje oszczędności. Początkowo pokojowy marsz zmienił się w krwawe

${ }^{7}$ Miasteczko to zostało założone w 1933 r. po odkryciu w tej okolicy bogatych złóż ropy naftowej, a jego funkcjonowanie uzależnione i podporządkowane było rytmowi przemysłu paliwowego (Auyero 2004). Zamknięcie zakładu oznaczało utratę głównego źródła dochodu dla tysięcy mieszkańców i ich rodzin.

8 Świadczą chociażby o tym dane o „aktywności” na drogach: w 1997 r. w prowincji Buenos Aires zorganizowano 23 blokady dróg, a w 2002 r. było ich już 1100. Wzrost ten dotyczył całego kraju: 1997 r. - 77 blokad, a w 2002 r. — ponad 1600.

${ }^{9} \mathrm{~W} 1974 \mathrm{r}$. najbogatszych 10\% Argentyńczyków posiadało równowartość $28 \%$ PKB, a w $2000 \mathrm{r}$. wskaźnik ten wzrósł do $37 \%$. Z kolei dla $30 \%$ najuboższych wskaźnik ten spadł w omawianym okresie z 11\% do 8\% (Auyero 2000). 
starcia z policją (38 demonstrantów zginęło, setki osób zostało ciężko rannych, ponad 4,5 tys. aresztowano), doszło także do zamieszek ulicznych i plądrowania sklepów.

Tę „argentyńską Komunę Paryską” można postrzegać w kategoriach swoistego wydarzenia przeobrażeniowego (transformative event), które - jak uważa William Sewell (1996) — może zainicjować proces szerszych przemian świadomości i w konsekwencji przyczynić się do wybuchu rewolucji społecznej. Taki „mobilizujący” epizod może stać się punktem zwrotnym w historii danego ruchu społecznego, jednocząc uczestników i kanalizując ich energię w kierunku walki o zmianę sytuacji, w jakiej się znaleźli (Hess, Martin 2006). Jest to moment, w którym obywatele zaczynają kwestionować stare instytucje, domagając się zmiany statusu quo.

Wiele badań dotyczących tego zjawiska opisuje grudniowe powstanie jako moment przełomowy $\mathrm{w}$ argentyńskiej polityce, rozpoczynający nowy rewolucyjny okres radykalnych przemian zainicjowanych oddolnie przez obywateli (Dinerstein 2003; Zibechi 2003). Kryzys związany z wyczerpaniem się mandatu rządzących po raz pierwszy we współczesnej historii Argentyny doprowadził do obalenia rządu przez obywateli i odrzucenia klasy politycznej. Solidarność, jaka wówczas zapanowała, tchnęła w naród ducha walki i nadzieję na możliwość zmian, ujawniając ogromny potencjał tkwiący w społeczeństwie.

Ruch piqueteros przechodził różne „cykle protestu” (Tarrow 1998), co wiązało się ze zmianą liczby oraz stopnia zaangażowania uczestników, a także repertuaru stosowanych strategii. Pierwsza fala masowej mobilizacji nastąpiła między styczniem a lipcem 2002 r. ${ }^{10}$ Był to etap określany przez badaczy ruchów społecznych jako plateau (Chesters, Welsh 2002, 2006), a więc okres intensywnego formowania się i zakorzeniania ruchu w szerszym kontekście społecznym, tworzenia jego tożsamości oraz wymiany doświadczeń i wzmacniania solidarności między uczestnikami, tak aby byli gotowi zaangażować się $\mathrm{w}$ ruch i ponosić związane $\mathrm{z}$ tym wyrzeczenia. Umożliwiło to $z$ kolei zbudowanie potencjału ruchu oraz stworzenie przestrzeni, także symbolicznej, dla różnych aktorów społecznych, którzy w późniejszym okresie, już jako faktyczni członkowie ruchu, podjęli szereg działań, których w innych okolicznościach, ze względu na swoją marginalną pozycję społeczną, nie mogliby zrealizować. Wszystko to było możliwe dzięki „sile słabych więzi” (Granovetter 1973) oraz stworzeniu rozbudowanych „sieci małych światów” (Barabási 2002; Buchanan 2002), co z pewnością zwiększyło ich, nieznaczny na początku, potencjał społeczny. Pewien odpływ uczestników miał miejsce między sierpniem 2002 r. a majem 2003 r., co zbiegło się z przyznaniem przez rząd zasiłków dla bezrobot-

10 Według niektórych szacunków, od grudnia 2001 r. do czerwca 2002 r. rozpowszechniający się ruch stał się znaczącą i widoczną siłą, a w różnych działaniach piqueteros brało udział blisko 4 milionów osób (CS 2003, s. 117). 
nych, wewnętrznymi sporami między różnymi organizacjami i wielkimi nadziejami, jakie wiązano $z$ wyborem na prezydenta Néstora Kirchnera (maj 2003) (Auyero 2004). Intensywność ruchu malała także za jego rządów, w miarę jak „dokooptowywał” wielu liderów piqueteros do administracji państwowej oraz finansował niektóre ich projekty. Jednak początkowe nadzieje związane $z$ rządami Kirchnera szybko zostały rozwiane, gdy okazało się, że pomoc obiecana bezrobotnym jest fikcją. Poza tym wzrosły ceny oraz wskaźniki niedożywienia wśród dzieci. Niezadowolenie zaczęło przybierać na sile wiosną 2004 r., gdy początkowo nieliczne organizacje w odpowiedzi na zamrożenie pensji i rosnące bezrobocie zainicjowały masowe blokady dróg (Petras 2004). Działania te ponownie zaktywizowały tysiące obywateli, którzy chcieli wywrzeć presję na rządzących, manifestując swoje niezadowolenie i domagając się spełnienia wcześniejszych postulatów.

\section{BEZ ZIEMI, BEZ PRACY, BEZ DOCHODU, ALE NIE BEZ NADZIEI}

Początkowo piqueteros byli ruchem chaotycznym, zorganizowanym wyłącznie na poziomie lokalnym, a ich działania miały na celu zaspokajanie konkretnych, krótkoterminowych potrzeb partykularnych grup protestujących. Chodziło im głównie o zapewnienie pracy, opieki medycznej oraz żywności. W pierwszym okresie protestów bezrobotnych uznawano za pewną osobliwość, wyjątek od reguły, przykład „usterki” w ramach systemu, którą z pewnością da się naprawić, aby w ostateczności usunąć problem. Stopniowo jednak, wraz z pogłębianiem się kryzysu społeczno-ekonomicznego, przekształcając się w symboliczną reprezentację bezrobotnych z całego kraju, ruch stawał się coraz lepiej zorganizowany. Był to, jak pisze Luis Oviedo (2002, s. 59): „sporadyczny i spazmatyczny protest przeciwko konkretnej sytuacji, który z biegiem lat, przy stale utrzymującej się recesji i niewydolności rządu, przeobraził się $\mathrm{w}$ pozytywny ruch, który stworzył i tworzy przestrzeń społeczną oraz polityczną dla bezrobotnych i wykluczonych".

$\mathrm{Z}$ jednej strony wydawać by się mogło, iż bezrobotni i osoby wykluczone ze społeczeństwa są potencjalną klientelą radykalnych ruchów społecznych, stanowiąc trzon wszelkich rewolucji czy powszechnych buntów, gdyż ich niezadowolenie wynikające $z$ poczucia relatywnej deprywacji sprzyja radykalnym działaniom. Z drugiej strony, ze względu na pozycję w strukturze społecznej, brak pewności jutra i konieczność walki o codzienne przetrwanie, są oni postrzegani jako niezdolni do wyjścia poza partykularne potrzeby i zorganizowanie się na „wyższym”, politycznym poziomie. Co więcej, nierzadko ich poczucie własnej wartości jest mocno zachwiane, co również nie sprzyja budowaniu potencjału sprawczego, gdyż jak zauważa Susan James (1992, s. 60), kolektywne działanie wymaga „trwałego poczucia odrębnej tożsamości oraz zaufania, iż jest się wartym tego, aby uczestniczyć w życiu politycznym" (por. Lister 2007, s. 184). 
Pierre Bourdieu sugeruje, że aby można było zmobilizować bezrobotnych do walki o lepszą przyszłość, muszą oni mieć zapewnioną odrobinę materialnej pewności, co przynajmniej w jakimś sensie pozwoli im odzyskać zatracone poczucie własnej wartości czy przełamać wykluczenie z sieci czasowo-przestrzennych powiązań (Bourdieu 1998, s. 83). Ich przystąpienie do ruchu jest swoistym przywracaniem owej godności, co nadaje im symboliczną władzę i siłę w walce o lepszą przyszłość. W ten sposób stają się swego rodzaju ikoną walki i jej namacalnym przejawem.

Wydaje się, iż tym, co w dużej mierze ogranicza i blokuje działania wykluczonych, jest ciężar związany z przeświadczeniem, że jakiekolwiek publiczne ujawnienie się będzie potwierdzeniem ich osobistej nieudolności oraz wystawieniem się na zarzuty o nieróbstwo i chęć życia na koszt społeczeństwa. Bierność bezrobotnych i wykluczonych często jest związana ze stereotypowym postrzeganiem własnej sytuacji oraz tego, jak są postrzegani przez innych. Potwierdzają to również te badania, z których wynika, iż ubóstwo kojarzone jest często $z$ niskim poziomem zaangażowania politycznego, obywatelskiego oraz postrzeganiem biednych jako tych, którym brakuje „sprawczego potencjału politycznego oraz zdolności do aktywności społecznej" (Lister 2007, s. 183; por. Goode, Maskovsky 2001, s. 14). Poza tym do wspólnego działania potrzebne jest również poczucie tożsamości kategorialnej, a doświadczanie ubóstwa, jak zauważa Ruth Lister (2007, s. 184), często narusza tożsamość (ontologiczną i kategorialną) oraz podmiotowość, co z pewnością nie ułatwia osobom żyjącym w biedzie wspólnego działania.

Przykład piqueteros wyraźnie pokazuje jednak, że sceptycyzm ów nie jest do końca uzasadniony. Okazuje się bowiem, iż w określonych okolicznościach osoby wykluczone $z$ głównego nurtu życia społecznego mogą zjednoczyć się i działać dla dobra wspólnego, ujawniając swój potencjał sprawczy. Potwierdza to również brytyjska badaczka biedy Ruth Lister (2007, s. 183), która zauważa, iż ludzie żyjący w biedzie mimo ewidentnych przeszkód i ograniczeń nierzadko podejmują działania o charakterze prowspólnotowym - czy to $\mathrm{w}$ formie zbiorowej samopomocy, czy bezpośrednich działań politycznych. Co więcej, ich determinizm i potencjał może być nawet większy, chociażby $z$ tego względu, iż mają niewiele do stracenia. Ponadto takie publiczne działanie przywraca ich społeczeństwu. Są już nie tylko wyrzutem sumienia, skrywanym głęboko z obawy przed upublicznieniem, ale stają się podmiotem działającym po to, aby udowodnić opinii publicznej, iż często są ofiarami nieefektywnego, wadliwego systemu, który faworyzuje silnych. Takie działanie w sposób symboliczny wymazuje przypisywane im winy, przyczyniając się do zmiany społecznie podzielanych i powielanych poglądów na temat ludzi żyjących $\mathrm{w}$ biedzie. $\mathrm{W}$ ten sposób zrzucają oni ciężar bycia uznanym za jednostkę nieporadną, niezdolną dostosować się do zmieniających się reguł, przerzucając całą winę na wadliwie działający system społeczno-ekonomiczny. To „poznawcze wyzwolenie”, jak twierdzi Dough McAdam (1982, s. 51-52), jest niezbędnym warunkiem 
wstępnej mobilizacji ruchu społecznego lub rewolucji. Zanim dojdzie do wybuchu zbiorowego protestu, jego potencjalni uczestnicy muszą zdefiniować swoje położenie jako niesprawiedliwe i wymagające zmiany na drodze wspólnego działania. Proces samouświadamiania mobilizuje jednostki do działania. Jak zauważył Paulo Freire (1970), kluczowym składnikiem upodmiotowienia jest krytyczna świadomość. To właśnie uświadomienie sobie społecznego wymiaru indywidualnego problemu pozwala jednostce na konstruktywne spojrzenie na własną sytuację i uruchamia proces poszukiwania sposobów rozwiązania danego problemu, często $\mathrm{w}$ wyniku kolektywnego działania.

\section{„BRAK” JAKO WARTOŚĆ KONSTYTUUJĄCA DZIAŁANIE}

Specyfiką omawianego ruchu jest budowanie własnej tożsamości i podstawy działania przez wykorzystanie i zaadaptowanie szeroko pojętego „braku”. Ten „brak” (pracy, zameldowania, dochodu, ziemi, nadziei na przyszłość itd.) staje się kluczową kategorią, która odpowiednio przedefiniowana nabiera innego sensu, pozwalając uczestnikom ruchu na wyjście poza przestrzeń wykluczenia i marginalizacji. Przedefiniowanie negatywnej tożsamości oraz jej afirmacja pozwalają na zupełnie nowe praktyki. Jak twierdzą Jordan i Weedon (1995, s. 5): „dla grup zmarginalizowanych i opresjonowanych tworzenie nowej tożsamości jest kluczowym czynnikiem umożliwiającym szerszą walkę polityczną". Trudno nie zgodzić się z Luisem Oviedo, który zauważa, że „ruch piqueteros, poprzez organizowanie tych, którzy $z$ racji swojej sytuacji są zdezorganizowani, jest próbą przełamania związanej z bezrobociem atomizacji klasy pracującej" (Oviedo 2002, s. 1). W toku wspólnych działań zmienia się status jednostki - wcześniej potencjalnie oskarżona o nieudolność staje się obywatelem, który może sam oskarżać, a grupy pozornie zatomizowanych jednostek konstutuują silny ruch. Ruch piqueteros walczy de facto o nadanie innego znaczenia kategoriom takim jak „obywatel”, „reprezentacja polityczna” i „uczestnictwo”, a także dąży do przedefiniowania pojęcia demokracji (Alvarez, Dagnino 1998, s. 2).

Metody stosowane przez piqueteros nie są nowe, gdyż barykady, strajki i demonstracje od zawsze były sposobem wyrażenia niezadowolenia przez ruchy robotnicze. Różnica polega na tym, iż tradycyjnie robotnicy koncentrowali się raczej w swoich działaniach na fabryce, a więc na przestrzeni „wewnętrznej”, ograniczonej w zasadzie murami zakładu, a ich organizacja często opierała się na strukturze hierarchicznej. Piqueteros przełamali te zasady, wychodząc poza mury fabryk, otwierając się na szerszy kontekst i dzięki temu wkraczając do społecznego krwiobiegu. To potwierdza ich przynależność do tzw. nowych ruchów protestu (Brandt 1982), które - w przeciwieństwie do tych z końca wieku XIX i z początków XX - cechuje większy egalitaryzm członków, autonomia, nieformalność, spontaniczność, raczej inkluzywność niż ekskluzywność oraz skoncentrowanie na celach, które nie tylko są istotne z punktu widzenia 
ruchu, lecz mają znaczenie także dla całego społeczeństwa. Ruchy te, na co wskazuje David Solnit (2004) są swoistymi „laboratoriami oporu”. Ich uczestnicy przejmują bezpośrednią kontrolę nad własnym działaniem, nie czekając na pomoc z zewnątrz, a w organizacji opierają się nie na hierarchii i wertykalnych relacjach władzy, lecz raczej na horyzontalnym podejmowaniu decyzji.

Owa inkluzywność oraz brak zaplecza instytucjonalno-strukturalnego jest wyraźnie widoczna w przypadku piqueteros. Bohaterami i trzonem ruchu są osoby biedne i wykluczone, funkcjonujące na marginesie społeczeństwa lub nawet poza jego ramami. Należą do niego bezdomni, bezrobotni, osoby zatrudnione na peryferiach rynku pracy, wykonujące niepewne i nisko płatne prace, rolnicy pozbawieni ziemi, mieszkańcy ubogich przedmieść, bezrobotna młodzież, niepracujące kobiety. Większość z nich przystąpiła do ruchu powodowana głodem, ubóstwem oraz świadomością, że nie mają nic do stracenia. Przeważająca część nigdy nie miała żadnych doświadczeń w organizowaniu akcji protestacyjnych (CS 2004, s. 69).

Ta niewidzialna do niedawna część społeczeństwa stała się widzialna dzięki spektakularnym akcjom, polegającym głównie na blokowaniu dróg, co skutecznie paraliżuje miasta i całe rejony kraju. Akcje te są przedsięwzięciami masowymi, blokady dróg nierzadko trwają kilka dni. Piqueteros wznoszą barykady z płonących opon, samochodów, a tysiące osób siedzą na drodze, organizując sobie tam namiastkę normalnego życia: gotują, jedzą, śpią, a czasami nawet zapraszają do siebie grupy artystyczne, które urozmaicają im czas, zwiększając tym samym wymiar tego happeningu oraz nadając całemu przedsięwzięciu charakter niepowtarzalnego show. Działania te wykraczają poza konwencjonalne formy politycznej ekspresji, ale właśnie $\mathrm{w}$ niekonwencjonalności tkwi siła kształtowania opinii publicznej oraz wywierania wpływu na rządzących. Im większa bowiem spektakularność działań, tym większe prawdopodobieństwo znalezienia się w mediach i przebicia się do powszechnej świadomości. Dzięki tym symbolicznym działaniom skutecznie przyciągają uwagę, a blokując ważne węzły komunikacyjne symbolicznie przejmują - przynajmniej na pewien czas - kontrolę, ze zmarginalizowanych i spychanych bezrobotnych i bezdomnych stając się bohaterami wydarzeń. Jak zauważa filozof José Pablo Feinmann: „,bezrobotny w trakcie zgromadzenia, pikiety czy marszu przestaje być człowiekiem zbędnym, upokorzonym, odzyskuje tożsamość i wartość [...]. Jest kimś. Coś od niego zależy, o czymś decyduje" (cyt. za: Domosławski 2002). Powoduje to czasowe odwrócenie ról, dominację nad tymi, którzy w pewnym sensie przyczynili się do wypaczenia ich życia i do warunków, w jakich egzystują.

Oczywiście blokady, aczkolwiek ważne, chociażby ze względu na swoją spektakularność, nie są jedyną formą działania piqueteros. Wraz z upływem czasu do ruchu przystępowały różne organizacje, które przedstawiały swoje propozycje konkretnych zmian społecznych. Nastąpiła transformacja i rozkwit ruchu, który choć zaczynał od sporadycznych, spontanicznych i bardzo „spazmatycznych" protestów w obronie partykularnych interesów, stopniowo prze- 
mienił się w platformę dążeń do przywrócenia sfery publicznej tym, którzy do tej pory byli z niej wykluczeni. Jak pisze Piotr Sztompka skuteczność ruchu zależy od jego potencjału strukturacji, który powinien obejmować zarówno potencjał destrukcyjny (zakłócający), jak i twórczy (konstruktywny). Ruch, aby mógł być uznany za pełnoprawny i znaczący historycznie, powinien nie tylko osłabiać istniejące struktury, ale także próbować wprowadzać na ich miejsce nowe regulacje (Sztompka 2005, s. 226). Wydaje się, iż piqueteros można pod tym względem uznać za ruch pełnoprawny, gdyż w swoich działaniach nie ogranicza się on jedynie do krytyki i podważania status quo, lecz wykazuje również silny potencjał konstruktywny, zmierzając do tworzenia rzeczywistości społecznej opartej na nowych zasadach i wartościach.

Obecnie coraz częściej członkowie ruchu protestują przeciwko stosowaniu nazwy piqueteros, która zwraca uwagę na pikiety jako praktykę konstytuującą ruch. Praktyka ta poniekąd należy do poprzedniego etapu ich działania, teraz zaś, wraz z konsolidacją ruchu, większy nacisk kładą na codzienne działanie w ramach i dla dobra wspólnoty (Auyero 2005). Przyczyniło się to do społecznego uznania ruchu, legitymizacji jego istnienia oraz stosowanych praktyk ${ }^{11}$. Ogólnie niekorzystna sytuacja społeczno-ekonomiczna uświadomiła pozostałej części społeczeństwa, iż piqueteros - reprezentanci najsłabszego ogniowa - są pierwszymi ofiarami niewydolnego systemu, a ich los może w zasadzie dotknąć każdego. Poza tym sam ruch dzięki uświadamianiu sobie własnego znaczenia i roli nabierał spoistości, wychodząc poza partykularne, lokalne żądania, coraz bardziej skutecznie włączając się w dyskurs publiczny i artykułując wyraźnie swoje postulaty. W ten sposób potępiali oni nie tyle konkretne wydarzenia, ile obowiązujący model społeczno-gospodarczy oraz jego autorów.

Jedną z form „pozarebelianckiej” działalności ruchu są zgromadzenia ludowe, które powstają $\mathrm{w}$ fabrykach, w dzielnicach, na uniwersytetach i w szkołach. Pełnią one funkcję organów władzy bezpośredniej, ich członkowie są wybierani spośród przedstawicieli społeczności lokalnej. Stanowią platformę wspólnego działania, dzięki której uczestnicy mogą faktycznie zrobić coś dla innych. Przywoływany już wcześniej Feinmann mówi, iż udział w nich jest aktem prowspólnotowym, gdyż „ten, kto idzie na zgromadzenie sąsiadów, żeby spotkać «innych», samym aktem pójścia tworzy «nas». "Ja» $\mathrm{i}$ «inni» zaczynamy mówić o sobie «my». Zgromadzenie czyni z nas wspólnotę" (cyt. za: Domosławski 2002). Działanie w ramach ruchu staje się dla działaczy źródłem tożsamości, zapewniając im zakorzenienie oraz gwarantując tym samym swego rodzaju „bezpieczeństwo ontologiczne”, mimo oczywistego niepokoju egzystencjalnego, jaki towarzyszy ich codziennym zmaganiom z rzeczywistością (Giddens 2002, s. 50).

11 Początkowo większość Argentyńczyków negatywnie odnosiła się do blokad i pikiet, które paraliżowały miasta, utrudniając życie mieszkańcom, lecz z czasem uznała takie działania za prawo piqueteros do walki o swoje interesy (CS 2003, s. 62). 
Zgromadzenia są alternatywą dla instytucji państwowych, które utraciły zaufanie społeczne. W obradach biorą udział przedstawiciele wielu warstw społecznych, czujący się ofiarami systemu, od bezrobotnych po pracujących i przedstawicieli drobnego biznesu, lekarzy, kobiety z przedmieść, młodzież. Dyskutowane są kwestie przyszłości kraju, sposoby wyjścia z kryzysu, a także zagadnienia związane $z$ bieżącymi i doraźnymi problemami typowymi dla danej wspólnoty lokalnej. Realizowane są także konkretne przedsięwzięcia. Zgromadzenia wprowadziły system samopomocy, zatrudniają bezrobotnych (głównie na zasadach spółdzielni społecznych), organizują życie kulturalne, prowadzą także wiele innych działań. Ich rola wzrasta, na przykład władze Buenos Aires zaprosiły niektórych $z$ ich przedstawicieli do stworzenia wspólnych komisji do spraw dystrybucji pomocy rządowej przeznaczonej dla najuboższych.

\section{RUCH PIQUETEROS NIEJEDNO MA IMIĘ...}

Ruch piqueteros nie jest jednolitym ruchem społecznym, lecz forum skupiającym wiele różnych grup społecznych i organizacji, od członków związków zawodowych po przedstawicieli masy ubogich, których przyciąga nadzieja na odmianę losu. I choć ta różnorodność z jednej strony stanowi o sile i żywotności ruchu, z drugiej strony jest potencjalnym źródłem konfliktu i rozłamów między suborganizacjami, które prezentują nieco odmienne wizje świata i sposobów realizacji swoich celów. Są one kontrolowane przez lokalnych liderów lub przez niewielkie partie lewicowe, które chroniąc partykularne interesy, celowo antagonizują poszczególne grupy, uniemożliwiając zjednoczenie na poziomie dzielnicy, nie mówiąc już o całym kraju.

Taki ideologiczny i polityczny podział właściwie istniał od samego początku, ale wraz $z$ upływem czasu i rozszerzaniem pola działania niezgoda co do pewnych celów stawała się coraz bardziej dotkliwa. Różne opcje ideologiczne $\mathrm{w}$ obrębie ruchu nierzadko ostro konkurowały ze sobą, co utrudniało komunikację i współpracę. Wydaje się jednak, że mimo podziałów istnieje pewna spójna wizja wewnętrznej organizacji (horyzontalność i nieformalność więzi opartych na wzajemnym zaufaniu, a nie na wymuszonym podporządkowaniu), sposobu podejmowania decyzji (dialogiczność) oraz sposobu bezpośredniego działania (pikiety, blokady dróg). Wizję tę podzielają łączący się pod wspólnym sztandarem - niezgody na zaistniałą sytuację i walki o lepszą przyszłość.

Zasadnicze różnice dotyczą sposobów walki, a w szczególności tego, czy współpracować $\mathrm{z}$ władzami i próbować zmieniać rzeczywistość $\mathrm{w}$ ramach istniejącego systemu politycznego, czy też całkowicie się odizolować od głównego nurtu władzy, elit rządzących i własną, codzienną, żmudną pracą „u podstaw" zmieniać świat. Stawiane jest pytanie, w jaki sposób wykorzystywać rządową pomoc (czy ją w ogóle brać) i czy warto negocjować z rządzący- 
$\mathrm{mi}^{12}$. Gdyby na podstawie odpowiedzi na to pytanie - będące odzwierciedleniem odwiecznych dylematów rewolucjonistów: reformy czy rewolucja dokonać podziału ruchu, to po jednej stronie znalazłyby się takie organizacje, jak CCC (Corrinte Clasista y Combativa) oraz FTV (Federacion de Tierra y Vivienda), a po drugiej: Bloque Piquetero, MIJD (Movimiento Indipendiente de Jubilados y Desocupados), MTD (Movimeiento Trabajadores Desempleados), Anibal Veron czy Barrios de Pie.

Organizacje $z$ pierwszej grupy decydują się na dłuższą współpracę z rządem i częściowo wchodzą do zinstytucjonalizowanych struktur politycznych, uznając, iż jest to najszybszy i najskuteczniejszy sposób działania. W początkowym okresie grupa współpracująca $z$ władzą odniosła określone, acz krótkotrwałe korzyści (dodatkowe plany pracy, dofinansowanie na niewielką skalę itp.). Początkowo ruch piqueteros był kryminalizowany zarówno w mediach, jak i w publicznych wypowiedziach przedstawicieli rządu, ale $\mathrm{w}$ miarę zyskiwania znaczenia politycznego i nabierania podmiotowości zaczął być brany pod uwagę. Rząd, który niegdyś potępiał ich za radykalizm działań, obecnie zaprasza liderów ruchu do negocjacji w sprawach polityki. Wiele organizacji związkowych, które wcześniej nie popierały piqueteros, odcinając się wręcz od nich, teraz próbuje zbliżyć się do nich. Może to wynikać ze strachu przed radykalnymi ruchami i przekonania, iż lepiej je mieć pod kontrolą niż pozwolić, aby ekstremiści i radykalni działacze stanowili zagrożenie dla porządku społecznego, a swoją nieobliczalnością zagrażali rządzącym.

Pierwotnie piqueteros zasadniczo odżegnywali się od formalnych, zinstytucjonalizowanych działań politycznych i byli niechętni włączaniu się $\mathrm{w}$ jakiekolwiek partie czy związki zawodowe, oskarżając je o wykluczenie i zubożenie znacznej części społeczeństwa. Zdawali sobie sprawę, iż ich siła leży właśnie w byciu poza formalnymi strukturami i „niebycie” politycznym. Ale po obaleniu głównych winowajców, odpowiedzialnych za kryzys w państwie, niektórzy działacze coraz chętniej spoglądają w stronę polityki ${ }^{13}$. Poza tym ugodowość i chęć współpracy z władzami została nagrodzona. Frakcje, które zdecydowały się na współpracę z rządem, uzyskały korzystne rozwiązania $\mathrm{w}$ ramach rządowych planów pracy, a nieprzejednani, którzy odrzucali współpracę, zostali poza systemem wsparcia.

12 Kwestia rządowych subsydiów ostro podzieliła ruch piqueteros. Rząd zaproponował pomoc dla ubogich i bezrobotnych, ale jej dystrybucją zajmowały się tylko niektóre organizacje, ponadto pomoc trafiła wyłącznie do tych, którzy mieli dobre układy z liderami danej organizacji lub stosowali się do ich wymagań (np. masowo uczestniczyli w demonstracjach). Reszta pozostała poza systemem pomocy rządowej i została wykluczona niejako wtórnie — przez „swoich”, którzy zastosowali zasady „obcych”. Ostatecznie pomoc stała się kartą przetargową mającą „złagodzić” radykalne żądania i uspokoić demonstrujących, doprowadziła przy tym do pęknięć w ich obozie i eskalacji wewnętrznych konfliktów (Oviedo 2002, s. 169).

13 Na przykład Luis d'Elia, lider FTV, kandydował na gubernatora Buenos Aires. 
Z kolei organizacje należące do drugiej grupy, opowiadające się za autonomią jako kluczem do sukcesu, nie chcą zostać włączone w główny nurt społeczny na zasadach podporządkowania, wolą walczyć w swoich środowiskach, zachowując odrębność. Nowi biedni zrozumieli bowiem, że ich sytuacja marginalności nie zostanie rozwiązana przez państwo, i zaczęli pracować na własne konto, aby zapewnić sobie codzienne przeżycie. Dlatego też nie opowiadają się za powrotem do „świata pracy” za wszelką cenę, gdyż mają świadomość, że mogliby tam funkcjonować jedynie jako członkowie drugiej kategorii, pogardzani i wykorzystywani. Zdecydowanie odrzucają możliwość współpracy z rządem. Stworzyli gęstą sieć różnego rodzaju punktów pomocowych, które zajmują się na przykład dożywianiem dzieci (tzw. kuchnie sąsiedzkie, hodowla zwierząt, uprawa ogrodów), edukacją (świetlice, biblioteki, zakładane przez piqueteros szkoły, w których rodzice mają decydujący głos, jeśli chodzi o wyznaczanie programów i metod wychowawczych), wytwarzaniem jedzenia dla podopiecznych (np. prowadzenie piekarń), zbiórkami odzieży, usługami remontowo-budowlanymi, podstawową opieką medyczną (np. bezpłatnymi szczepieniami dla dzieci) itp. Działania te w dużej mierze podejmowane są na zasadach wolontariatu (np. praca na rzecz dobra wspólnego w wymiarze czterech godzin tygodniowo) lub produkcji na zasadach spółdzielni społecznych (np. drukarnie) (Oviedo 2002) ${ }^{14}$. Mają za zadanie krzewienie wspólnotowości, zasad wzajemnej współpracy i tworzenie sieci samopomocowych. Jest to przestrzeń „Współ-bycia” poza czasem pikiet i blokad, zapewniająca uczestnikom ciągłość i poczucie bezpieczeństwa $\mathrm{w}$ życiu codziennym, a nie tylko z okazji masowych demonstracji. Niektóre $z$ tych organizacji (np. Anibal Veron) zaczęły praktykować nowe formy demokratycznego działania, w których ważną rolę odgrywa koncepcja demokracji uczestniczącej. Organizacje te prowadzą swoje prace nie-

\footnotetext{
14 Obecnie w Argentynie podejmowane są prawdziwe eksperymenty związane z samorządnością i uniezależnianiem się od władzy. Wciąż dynamicznie rozwija się ruch przejmowania (odzyskiwania) fabryk państwowych zamykanych z powodu upadłości w latach dziewięćdziesiątych, choć w wyniku represji i kontrdziałań państwa - stracił on swój początkowy impet. Pierwsza taka akcja odbyła się w 1985 r. w fabryce Forda, gdzie robotnicy przejęli władzę i opanowali produkcję na blisko trzy tygodnie. Dziś blisko dwieście przedsiębiorstw znajduje się w rękach wspólnot, które zarządzają ich działalnością. Szczyt tych działań przypadał na lata 2001-2002, kiedy w ponad stu przejętych fabrykach pracowało ok. 10 tys. robotników. Jednak rządy Duhalde’a i Kirchnera, wprowadzając stosowne ustawy, brutalnie usuwały robotników z fabryk. Część pracowników została „wchłonięta” przez rządowe plany dla bezrobotnych, część została zmuszona do przyjęcia orientacji na zysk i wycofania się z działalności spółdzielczej. Wiele z przejętych wcześniej przedsiębiorstw pracuje jako podwykonawcy dla prywatnych firm, nierzadko na niekorzystnych warunkach. Wyjątkiem jest duża fabryka ceramiki (Zanon), obecnie funkcjonująca jako FaSinPat (z hiszp. Fábrica Sin Patrones, a więc fabryka bez szefów), na zasadach spółdzielni, która zatrudnia ponad 400 pracowników, zwiększyła produkcję i zachowuje egalitarny system podziału pensji między robotnikami wykwalifikowanymi a niewykwalifikowanymi (Petras 2004). W fabryce pod rządami pracowników znacząco podniesiono pensje, wzrosła wydajność oraz bezpieczeństwo pracy. Utrzymuje ona dobre relacje z lokalną społecznością, współfinansując wiele projektów pro publico bono. Jednocześnie władze państwowe wielokrotnie próbowały przejąć przedsiębiorstwo i odebrać pracownikom autonomię. Na razie bez skutku.
} 
zależnie od formalnych mechanizmów demokratycznych, odmawiając udziału w wyborach, zarówno na szczeblu lokalnym, jak i narodowym, propagując demokrację inkluzyjną (Fotopoulos 1997). Ich postulaty, wyrażane podczas demonstracji, w gruncie rzeczy dotyczą żądania przyznania im funduszy na działalność.

Organizacje $z$ tej frakcji nie postulują zbudowania nowego idealnego społeczeństwa, ale opowiadają się za przeobrażaniem codziennej sytuacji „tu i teraz”. Ich działalność koncentruje się na przeprowadzaniu różnego rodzaju projektów o charakterze społecznym, politycznym, kulturalno-artystycznym w danej dzielnicy lub wśród rodzin związanych $z$ ruchem. Ich celem ma być próba, przynajmniej częściowego, rozwiązania takich problemów jak bezrobocie, niedożywienie dzieci czy niedostatki edukacji. Udział w nich osób biednych i wykluczonych ma zarazem zwiększać spójność społeczną oraz nadawać nowy wymiar ich codziennej, nierzadko bardzo trudnej egzystencji.

Członkowie ruchu uświadomili sobie, że najważniejsze staje się uzwyczajnienie działań, czyli wytwarzanie nowych struktur będących odpowiedzią na konkretne problemy społeczne oraz ich sedymentacja, a więc trwałe zakotwiczenie i uznanie zarówno przez aktorów organizacyjnych bezpośrednio w nie zaangażowanych, jak i decydentów (Tolbert, Zucker 1996, s. 182). Jest to możliwe zwłaszcza wtedy, gdy widoczne stają się pozytywne wyniki tych działań. Dlatego też piqueteros skoncentrowali się na działalności samopomocowej, tworzeniu gęstej sieci horyzontalnych więzi oraz propagowaniu demokracji inkluzywnej, zbudowanej wokół takich wartości jak autonomia, pluralizm, dialogiczność i poszanowanie różnorodności. Blokady i pikiety zaś są tylko zewnętrznym, spektakularnym i „zmedializowanym” wyrazem głębszych problemów, umożliwiają dotarcie do jak największej liczby osób.

Wcielają oni w życie specyficzną koncepcję rewolucji, która daleka jest od marksowsko-leninowskiej wizji „szturmu na pałace”, bliska zaś koncepcji refolucji Timothy'ego Gartona Asha. Jest to raczej „rewolucja życia codziennego” (Vaneigem 2004), która wiąże się z codziennymi, zmianami i mikrorewolucjami codzienności, będącymi w stanie wyrwać jednostkę z sideł niemocy. Działaczom przyświeca myśl, iż walka nie tylko powinna się toczyć na zewnątrz, ale ma być też codzienną praktyką i że najmniejsze problemy należy rozwiązywać tam, gdzie się pojawiają. Wynika to z przekonania, iż nie potrzeba wcale przejmować władzy, aby zmieniać rzeczywistość, gdyż źródło władzy — władzy ponadpolitycznej - tkwi właśnie w bezpośrednim działaniu, angażującym jednostki na co dzień (Holloway 2002). Jest to udział w społecznej transformacji na najniższym szczeblu. Angażowanie się w działania wraz z podobnymi sobie Innymi i wynikający $z$ tego wzrost poczucia indywidualnej i zbiorowej skuteczności oraz postrzeganie siebie w kategoriach podmiotu (a nie przedmiotu) i aktora (a nie tylko obserwatora) procesów społecznych to jeden $z$ elementów upodmiotowienia (empowerment) (Gutiérrez 1994). Tego typu aktywność umożliwia jednostkom dostrzeżenie społecznego wymiaru osobistych proble- 
mów i mobilizuje je do konkretnych działań ponadindywidualnych, mających na celu zmianę porządku społecznego.

Raul Zibechi, wybitny badacz ruchów społecznych w Ameryce Łacińskiej, w swojej książce dotyczącej korzeni argentyńskiej rewolty (2003) mówi, iż walka może rozgrywać się na dwa sposoby. Pierwszy to naturalna walka o egzystencję, drugi walka w rozumieniu militarnym. Ta pierwsza, polegająca na zapewnieniu sobie bytu, pochłania znaczną część energii ludzkiej. Ale jest kreatywna. Druga natomiast nakierowana jest na unicestwianie prawdziwego lub wyimaginowanego wroga. Różnica między nimi jest zasadnicza: „podczas, gdy walka będąca kreacją życia wymaga wysiłków solidarności i wzajemności międzyludzkiej, walka prowadzona zgodnie z logiką konfrontacji zakłada tworzenie mechanizmów destrukcji" (Zibechi 2003, s. 15). Zibechi twierdzi, iż orientacja stricte militarystyczna jest zgubna dla ruchów społecznych i sprawia, że odtwarzają one mechanizmy i formy wyzysku oraz dominacji, przeciwko którym jako ruchy emancypacyjne - tak naprawdę występują. Stwierdza on, iż szeroko pojęte braterstwo, nie zaś wojna, jest kluczem do zmiany społecznej. Braterstwo, jako jeden z głównych motywów rewolucji francuskiej, wyznacza drogę równości i wolności (Zibechi 2003, s. 18).

\section{ZAKORZENIANIE WYKORZENIONYCH}

Pojawienie się ruchu piqueteros było niejako naturalną konsekwencją narastającego od lat kryzysu społeczno-gospodarczego. Jednak jego zaistnienie na płaszczyźnie symbolicznej to z pewnością niemała rewolucja. $\mathrm{Ci}$, którzy do tej pory byli wykluczeni z jakiejkolwiek działalności produkcyjnej czy konsumpcyjnej, społecznie wyklęci i uznani za niegodnych uczestniczenia w życiu zbiorowym, wraz z przystąpieniem do ruchu stali się na nowo obywatelami z niewidzialnych stali się znowu „widzialni i słyszalni”. Zbudowali wewnętrzną sieć różnego rodzaju działań, organizując się wokół swoich małych, codziennych celów i osiągnięć. Z punktu widzenia poziomu makro faktyczna rewolucja, polegająca na zburzeniu „starego” i zbudowaniu zupełnie nowego „wspaniałego świata", nie nastąpiła, neoliberalizm ma się w Argentynie całkiem dobrze, a wyeliminowanie ubóstwa i bezrobocia nadal pozostaje w sferze marzeń. Ale też nie tylko o to piqueteros chodziło. Zyskali podmiotowość oraz odzyskali część zawłaszczonej przez innych przestrzeni publicznej, wydzielając swoje pole do negocjacji. Zostali uznani i są rozpoznawalni jako ważny podmiot społeczny i polityczny. Tylko tyle i aż tyle. Jednak ich siła jest bezsprzeczna. Ruch piqueteros jest bowiem dzisiaj najsilniejszą opozycją w kraju, z roku na rok dołączają do niego nowi członkowie.

Nie można pomijać ich działania na poziomie symbolicznym oraz faktu, iż nierzadko „dyskurs i praktyki ruchów społecznych mogą destabilizować, a dzięki temu w pewien sposób również przeobrażać, przynajmniej częściowo, dominujące dyskursy oraz praktyki wykluczające istniejące $\mathrm{w}$ dominującym 
systemie" (Alvarez, Dagnino 1998, s. 11), a to — jak uważa Pierre Bourdieu (1998, s. 83) - może oznaczać, iż „symboliczny porządek, który jest warunkiem funkcjonowania porządku ekonomicznego, może zacząć pękać”. Wtóruje mu Evelina Dagnino (1998, s. 37), która podkreśla, iż „pewne sposoby przejawiania się hegemonii wytwarzane są w sferze kultury”, a więc na poziomie symbolicznym. Wszelkie próby podważenia tego porządku mogą stać się zatem zaczątkiem zmian $z$ innego poziomu. Rewolucja może być owocem działań na wielu frontach, różnymi metodami, pod różną postacią, a jej zwycięstwo niekoniecznie musi oznaczać powstanie partii czy gwałtowne przejęcie władzy, ale raczej stworzenie demokratycznej przestrzeni, w której swoje miejsce i możliwość ekspresji znajdą także do tej pory wykluczeni. Działalność ruchów takich jak piqueteros jest właśnie próbą „przedefiniowania znaczenia oraz granic systemu politycznego" (Alvarez, Dagnino 1998, s. 5).

W odniesieniu do ruchów społecznych możemy mówić, jak zauważył Alberto Melucci (1989), o co najmniej dwóch wymiarach istnienia: po pierwsze, są to działania, które w sposób konkretny przyczyniają się do zmiany społecznej; po drugie - znaki, świadczące o tym, iż pewien obszar życia społecznego zaczyna być kwestionowany, wskazujące jednocześnie, że alternatywa dla istniejącego porządku - choć trudno wyobrażalna - jest możliwa. Ruch piqueteros jest niewątpliwym świadectwem transformacji społecznej, doskonałym przykładem mobilizacji tych, którzy zepchnięci w cień, postanowili wreszcie przemówić donośnym głosem, zmuszając decydentów i opinię publiczną, po pierwsze, do dostrzeżenia faktu, iż istnieją, a po drugie, do zmierzenia się $z$ problemem, który dotyczy niemałej części argentyńskiego społeczeństwa. Ignorowanie powiększającego się „świata wykluczonych” jest praktyką krótkowzroczną. Należałoby się raczej wsłuchać w ich słowa i spróbować odpowiedzieć na ich apele. Jednak aby to się stało, nie wystarczy wola polityczna. Prawdziwa rewolucja musi wydarzyć się w sferze mentalnej, na poziomie świadomości społecznej, która „otworzy się” na pozostałych poza granicami świata społecznego. Jak widać na przykładzie Argentyny to, co wydawało się niemożliwe i budowane na chybotliwych fundamentach, stanowiących najsłabsze ogniwo systemu, odpowiednio wzmocnione, stało się prawdziwą siłą, która jest w stanie, choćby w niewielkim stopniu, odmienić los biednych i wykluczanych, napełniając ich nadzieją, a także symbolicznie przywracając społeczeństwu.

\section{BIBLIOGRAFIA}

Alverez Sonia, Dagnino Evelina, 1998, Introduction: The Cultural and the Political in Latin American Social Movements, w: Sonia Alverez, Evelina Dagnino, Arturo Escobar, Cultures of Politics, Politics of Culture: Re-visioning Latin American Social Movements, Westview Press, Oxford.

Arrighi Giovanni, Hopkins Terence K., Wallerstein Immanuel, 1989, Antisistemic Movements, Verso, London-New York. 
Auyero Javier, 2000, The Hyper-Shantytown: Neo-Liberal Violence(s) In the Argentine Slum, „Ethnography”, t. 1, s, 93-116.

Auyero Javier, 2004, When Everyday Life, Routine Politics, and Protest Meet, „Theory and Society", t. 33, s. 417-441.

Auyero Javier, 2005, Protest in Contemporary Argentina: A Contentious Repertoire in the Making, w: Patricia Fernández-Kelly, Jon Shefner (red.), Out of the Shadows: Political Action and the Informal Economy in Latin America, Pennsylvania State University Press, University Park, Pa.

Barabási Albert-László, 2002, Linked: The New Science of Networks, Perseus Publishing, Cambridge, Mass.

Bateson Gregory, 1973, Steps to an Ecology of Mind, Paladin, London.

Bourdieu Pierre, 1998, Job Insecurity Is Everywhere Now, w: Pierre Bourdieu, Acts of Resistance: Against the Tyranny of Market, The New Press, New York.

Bourdieu Pierre, 1999, Pour un mouvement social européen, „Le Monde Diplomatique”, Juin.

Brandt Karl-Werner, 1982, Neue soziale Bewegungen: Entstehung, Funktion und Perspektive neuer Protestpotentiale, Westdeutscher Verlag, Opladen.

Buchanan Mark, 2002, Small World: Uncovering Nature's Hidden Networks, Weidenfeld and Nicolson, London.

Chesters Graeme, Welsh Ian, 2002, „Reflexive Framing: An Ecology of Action, Globalization and the Environment", XV World Congress of Sociology, 6-13 czerwca, Brisbane, Australia (http://www.shiftingground.freeuk.com/isapaper.htm).

Chesters Graeme, Welsh Ian, 2006, „The Death of Collective Identity? Global Movement as a Parallelogram of Forces", International Sociological Association's XVI World Congress, 23-29 lipca, Durban (http://www.brad.ac.uk/acad/icps/publications/ papers/Death_of_collective_identity.pdf).

CS, 2003, Colectivo Situaciones, Piqueteros - la rivolta argentina contro il neoliberalismo, Derrive Approdi, Roma.

Dagnino Evelina, 1998, Culture, Citizenship and Democracy, w: Sonia Alverez, Evelina Dagnino, Arturo Escobar, Cultures of Politics, Politics of Culture: Re-visioning Latin American Social Movements, Westview Press, Oxford.

Dinerstein Ana C., 2003, Power or Counter-Power? The Dilemma of the Piquetero Movement in Argentina Post-Crisis, "Capital \& Class”, t. 81, s. 1-8.

Domosławski Artur, 2002, Argentyna, „Gazeta Wyborcza”, Magazyn nr 12, 21 marca.

Fotopoulos Takis, 1997, Towards an Inclusive Democracy: The Crisis of the Growth Economy and the Need for a New Liberatory Project, Cassell, London.

Freire Paulo, 1970, Pedagogy of the Opressed, Continuum Publishing Co., New York.

Giddens Anthony, 2002, Nowoczesność i tożsamość. „Ja” i społeczeństwo w epoce późnej nowoczesności, tłum. Alina Szulżycka, Wydawnictwo Naukowe PWN, Warszawa.

Goode Judith, Maskovsky Jeff (red.), 2001, The New Poverty Studies: The Ethnography of Power, Politics and Impoverished People in the United States, New York University Press, New York-London.

Gutiérrez Lorraine, 1994, Beyond Coping: An Empowerment Perspective on Stressful Life Events, „Journal of Sociology and Social Welfare”, t. 21, s. 201-219.

Hess David, Martin Brian, 2006, Repression, Backfire, and the Theory of Transformative Events, „Mobilization”, t. 11, nr 1, s. 249-267.

Holloway John, 2002, Change the World Without Taking Power: The Meaning of Revolution Today, Pluto Press, London. 
INDEC, 2002, Instituto Nacional de Estadisticas y Censos (dane dostępne na stronie: www.indec.mecon.ar).

James Susan, 1992, The Good-enough Citizen, w: Gisela Brock, Susan James (red.), Beyond Equality and Difference: Citizenship, Feminist Politics, and Female Subjectivity, Routledge, London-New York.

Jordan Gleen, Weedon Chris, 1995, Cultural Politics: Class, Gender, Race and the Postmodern World, Blackwell, Oxford.

Kapuściński Ryszard, 2001, Wiosna ludów latynoskich, Rozmowa Artura Domostawskiego z Ryszardem Kapuścinskim, „Gazeta Wyborcza”, 4 lipca.

McAdam Doug, 1982, Political Process and the Development of Black Insurgency 1930-1970, The Chicago University Press, Chicago.

McAdam Doug, Snow David A. (red.), 1997, Social Movements: Readings on Their Emergence, Mobilization and Dynamics, Roxbury, Los Angeles.

Melucci Alberto, 1989, Nomads of the Present: Social Movements and Individual Needs in Contemporary Society, Century Hutchinson, London.

Lister Ruth, 2007, Bieda, tłum. Alina Stanaszek, Sic!, Warszawa.

Oviedo Luis, 2002, Una historia del movimiento Piquetero, Ediciones Rumbos, Buenos Aires.

Petras James, 2004, Argentina: From Popular Rebellion to „Normal Capitalism”, „Rebellion”, April.

Petras James, Veltmeyer Henry, 2002, Argentina: Between Disintegration And Revolution, „Covert Action Quarterly Magazine”, Fall.

Pinderhughes Elaine, 1995, Biracial Identity - Asset or Handicap?, w: Herbert W. Harris, Howard C. Blue, Ezra E. H. Griffith (red.), Racial and Ethnic Identity: Psychological Development and Creative Expression, Routledge, New York.

Smelser Neil, 1962, Theory of Collective Behaviour, Free Press, New York.

Snow David A., Soule Sarah A., Kriesi Hanspeter (red.), 2004, The Blackwell Companion to Social Movements, Blackwell, Malden, MA.

Solnit David (red.), 2004, Globalize Liberation: How to Uproot the System and Build a Better World, City Lights Books, San Francisco.

Sewell William A., 1996, Historical Events as Transformations of Structures: Inventing Revolution at the Bastille, „Theory and Society”, t. 25, s. 841-881.

Sztompka Piotr, 2005, Ruchy spoteczne - struktury in statu nascendi, w: Piotr Sztompka, Marek Kucia (red.), Socjologia. Lektury, Znak, Kraków.

Tarrow Sidney G., 1998, Power in Movement: Social Movements and Contentious Politics, Cambridge University Press, Cambridge-New York.

Taylor Verta, Van Dyke Nella, 2004, Get Up, Stand Up: Tactical Repertoires of Social Movements, w: David A. Snow, Sarah A. Soule, Hanspeter Kriesi (red.), The Blackwell Companion to Social Movements, Blackwell, Malden, MA.

Tilly Charles, 1986, The Contentious French, Belknap Press, Cambridge, Mass.

Tolbert Pamela, Zucker Lynne G., 1996, The Institutionalization of Institutional Theory, w: Handbook of Organization Studies, Steward Clegg, Cynthia Hardy, Wald K. Nord (red.), Sage, London.

Vaneigem Raoul, 2004, Rewolucja życia codziennego, tłum. Mateusz Kwaterko, Słowo/obraz terytoria, Gdańsk.

Zibechi Raul, 2003, Genealogía de la revuelta Argentina: la sociedad en movimiento, Letra Libre, Buenos Aires. 


\section{WITH HOPE AGAINST HOPELESSNESS - THE PIQUETEROS MOVEMENT AS AN EXAMPLE OF SELF-GOVERNANCE OF THE WORLD OF THE EXCLUDED}

\section{Summary}

In recent years democracy in South America has been challenged by many socio-political crises. One of the reactions to this system strain is the movement of piqueteros that emerged in Argentina mainly as a response to poverty, unemployment and inequality. The paper seeks to give some possible explanations for the rapid growth and present significance of this social movement. It also shows the structural and socio-political correlations that contributed to the success of the piqueteros, who without any institutional resources or political clout have become a powerful political actor. The case of the piqueteros may be an example of an effective mobilization of the latent and excluded groups of society who despite their apparent passivity can constitute an important element of social change.

\section{Key words/słowa kluczowe}

(new) social movements / (nowe) ruchy społeczne; the piqueteros / ruch piqueteros; unemployment / bezrobocie; poverty / ubóstwo; social change / zmiana społeczna; empowerment / upodmiotowienie; direct democracy / demokracja bezpośrednia; self-governance / samostanowienie 